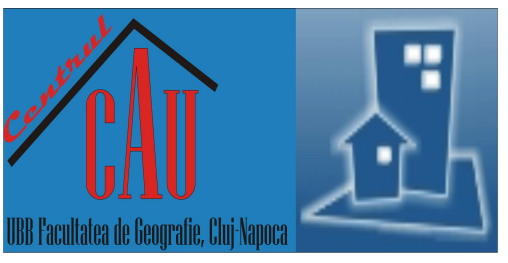

\title{
Regional Development Prospects for Sustainable Urbanization. Case Study - Qalaat Salih in Iraq
}

\author{
Sara Mahmood AL-JAWARI* ${ }^{{ }_{1}}$ \\ *Corresponding author \\ ${ }^{1}$ University of Kufa, Faculty of Physical Planning, Kufa, IRAQ \\ E-mail: sarahm.hpetr@uokufa.edu.iq \\ DOI: 10.24193/JSSP.2020.2.01
}

https://doi.org/10.24193/JSSP.2020.2.01

K e y w o r d s: urbanization, planning, regional development, development corridors, Qalat Salih, Iraq

\begin{abstract}
A B S T R A C T
The importance of regional development resides in the provision of aid and other assistance to regions that are less economically developed. The purpose of this research is to identify the development possibilities and resources at the regional level, which can be tapped for the development of secondary cities. This research aims to shed light on the importance of urban planning in creating regional balance and relieving population and service pressure on major cities. The research answers the question relative to how urban planners can work towards the idea of creating development corridors including the cities located within them, whilst focusing more on the regional dimension and the topic of sustainable urbanization. This research assumes the need for a development corridor between Amara and Basrah cities to facilitate increased and diverse social and economic development. Qalat Salih is a pole of development located on this development corridor; this paper follows the analysis approach for the regional potentials that can be exploited to activate the development corridor between Basra province and Amara, specifically in Qalat Saleh compared to Maysan districts. According to results, there are several development potentials at the regional level that can be exploited, namely natural resources and the existence of the marshes, as well as tourism activities/facilities that are present along the selected development corridor. It is therefore possible to explore potential import and export opportunities between districts, as well.
\end{abstract}

\section{INTRODUCTION}

The development plan for the urban expansion of Qalat Saleh in Missan governorate in southern Iraq was conducted by the United Nations Human Settlements Programme (UN-Habitat) under an EUfunded program. The adoption of Agenda 2030 for Sustainable Development emphasized the goals of sustainable development, such as making cities and human settlements inclusive, safe, resilient, and sustainable, whilst the economic corridors \& regional development consider the role in the development of the economy of the sub-region (Salat et al., 2017; Allen et al., 2016; Pantuliano et al., 2012). The future we want for cities is a future of opportunities, where everyone has access to basic services, energy, housing, transport, and more (UN Habitat, 2013). The world's largest and most competitive cities are paying less attention to the analytical study of secondary cities, although some of them are among the fastest-growing cities in the world (Rogerson, 2016; John et al., 2015). Rapid urbanization is accompanied by a large social and environmental cost; therefore, many secondary cities are poor, heavily pressurized by the development resulting from urbanization, and many of them are vulnerable and not take into consideration the urban development plans. This affects the provision of urban infrastructure and services. There are also development disparities between capital cities and major cities on one hand, and secondary cities and towns on the other (Roberts, 
2014). Therefore, there is a need to emphasize the role of secondary cities in sustainable urban development as they constitute a socio-economic link between rural communities and the major cities (Cities Alliance, 2007; Roberts, 2014).

Since Qalat Saleh represents a link between rural village communities on the one hand and the city of Amara, and the capital of Missan Governorate on the other, there is a need to study and control urbanization, taking into account all of the regional and urban environmental, economic, and social considerations to achieve sustainable urbanization. Across large areas of the developing world, a new trend has emerged, as governments are targeting public and private investments in specific geographic areas with the hope of creating spatial "development corridors". These strategies are guided by the belief that concentrating and co-locating infrastructure may lead to infrastructure investments in specific locations, which will in turn create clusters of interconnected cities, promote the development of value chains, reduce unemployment and improve the provision of basic public services (Cities Alliance, 2007; Faihan S, 2014).

Qalat Saleh is a secondary city located on one of the development corridors proposed in the Urban Development Strategy component for Missan Governorate. It is identified in the urban development report of the Ministry of Planning as a third-tier city, which is referred to small town located near rural areas, serving as marketing areas for their products and providing services (with a population ranging from 10,000 to less than 100,000 people).

The two main objectives of the Urban Development Strategy were also identified as:

a). Reducing disparities in development (unbalanced development) and in the level of service provision between rural and urban areas and between different governorates, as well as promoting integrated regional development.

b). Reducing the population concentration in the capital, governorate capitals, and major cities as well as take into consideration the growth of small and medium cities Therefore, there is a need for expansion and densification plans in order to accommodate the projected future growth in a sustainable manner. The main contributions of this paper are as follows:

c). Strengthening the specific developmental role to be played by secondary cities.

d). Promoting the development of rural and small settlements along the development corridor.

\section{LITERATURE REVIEW}

Development corridors have been studied by Müller-Mahn (2019) as dreamscapes of modernity in Africa. The study presented 3 elements of conceptual debates; the first element focused on how futures are 'made' and how practices of future-making can be empirically approached. The second element considered the imaginations of African futures in relation to the continents' image. The final element considered the empirical instance of development corridors in Africa to analyze their connotations as 'dreamscapes of modernity'. The study suggested the need to consider the post- and de-colonial positions and the "Theory from the south".

Another study by Wan et al. (2017) suggested a "Case of Hadaqi industrial corridor" in which case they used "GIS/RS technology and a system dynamics (SD) model for social development and the ecological environment" to investigate the Hadaqi industrial corridor in terms of coordinated development. From their results, it was observed that (i) there is a certain influence of population growth, but the major factor responsible for the deterioration of the ecological environment is predatory resources development and irrational development practices, (ii) it accounted for the lowest GDP growth on the inertia development model, the highest level of environmental pollution and resource consumption on the economic development model, least energy consumption, rapid economic growth, and least emission of pollutants on the PRED model, (iii) Hadaqi industrial corridor represents an area of high level interaction between people and nature both now and in the future. Athukorala and Narayanan (2018) focused on the economic corridors and regional development from the Malaysian perspective. The study considered economic corridors and their role in the development of the economy of the sub-region, focusing more on the elements involved in the development of economic corridors. Also they indicated the problems faced by infrastructural development within an equitable corridor development program. Explanations were also provided on the political economy of corridor design and governance in a federal system of government. Finally, the study indicated the policy options for Malaysia to achieve possible developmental gains from the Northern Economic Corridor.

Urban land and sustainable resource use have been studied by Wang (2020), focusing on urbanization and its countervailing effects on water use in China from 1990 to 2014. From the outcome of the study, the following points were highlighted:

a). Urbanization is associated with change in land use and population growth.

b). The mixed effects of urbanization are partly attributable to the varying effects of the two dimensions.

c). Growth in the number of urban population increases both the total and per capita water use.

d). Intensified land use results in long-run sustainable water use.

e). The impact of urban land usage is stronger on water efficiency compared to its effect on population growth. 
The study conducted by Martinuzzi et al. (2007) focused on land development and urban sprawl in Puerto Rico and identified three new regions for the studied area; the three regions are Urban (16\%), Densely Populated Rural (36\%), and Sparsely Populated Rural (48\%). Urban/built-up surfaces make up for $11 \%$ of the island and most of the developments are in the low-density construction patterns and sparsely populated areas. Meanwhile, 50\% of urban development occurs on the outskirts of urban centers. The aim of this analysis is to facilitate the differentiation of the landscape zones based on use and conditions; it also helps in the identification of both the urban/rural settings and the areas of development in regions dominated by pastures and forests, equivalent to a wildland-urban interface.

Catalán et al. (2008) focused on urban sprawl in the metropolitan region of Barcelona. The study compared two detailed land-cover maps of 1993 and 2000 and observed steady changes in the region's traditional urban nature. The dispersed urban model generalization was confirmed by lower urban densities, depopulation of the metropolitan inner core, high losses of non-urban land covers, an increasing need for single housing, and an increasing level of transportation facilities.

Creţan et al. (2016) focused on the anisotropic spaces in Romania; the study relied on the possible anisotropic matrix system based on the interpretation of human and material mobilities within the area. The study also systematically applied the theoretical framework of regional geography. The anisotropy concept was defined as a territorial anomaly in polarized and homogenous regions to identify the physical and social relations in which anisotropy is embedded.

Méreiné Berki et al. (2017) studied the social capital mechanisms in segregated urban underclass as well as the possible poverty alleviation interventions relating to social capital. The study examined the dynamics of the measures for poverty alleviation in relation to social capital by considering the experiences of a cooperative network to establish an artificial bridging capital by introducing local interpersonal relationships between the underclass and the mid-class, the patronage network that was introduced within a wider participatory action research (PAR) process. From the results, the ties and specific conditions necessary for daily living easily predominate the integration efforts of the system for social mobility and poverty alleviation with sustained and uncertain advantages for the segregated urban underclass.

Vesalon and Creţan (2019) studied the recent narratives of city branding in Timișoara, Romania by investigating one specific case in the reproduction and adaptation of global urban development policies, as well as to examine its relevance from the post-socialist urban politics perspective. The outcome of the study showed a specific circularity between city branding and urban development that helped in aligning the city to the regional inter-urban economic competition and in promoting it as a space for rapid development.

The importance of social capital in urban development Iraq is no exception in the geographical imbalance, the foreign direct investment (FDI) predominating in the states of the region. Considering the associated social risks, it is important for both the opportunities and the barriers posed by the poorer regions to be considered. Iraq is notorious for the substantial inequalities that exist under communism, dictatorship and Islamic parties; however, inhabitants are largely demarcated based on living standards and job opportunities; there are also general problems in the country due to the rapid increase in population, which outstripped the available employment, thereby necessitating movement to other regions, especially Baghdad and southern Iraq (Fahad and Ahmed, 2016). This decline in employment opportunities has heavily affected the industrial regions, especially the mining and industrial areas where the workers receive the highest salaries under dictatorship (Abdulkhaleq and Abdulqadir, 2017).

\section{RESULTS}

Qalat Saleh is a district of Missan province in the south of Iraq, located on the banks of the Tigris River, about $40 \mathrm{~km}$ from the governorate capital (Fig. 1).

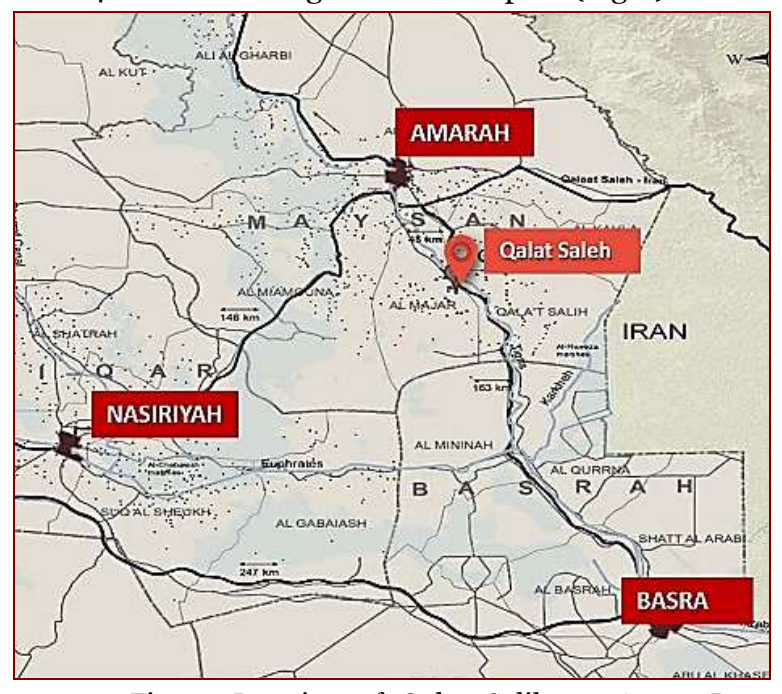

Fig. 1. Location of Qalat Salih on Amara-Basra highway (Source: Open Street Map-GIS).

The district population account for $9.9 \%$ of the governorate's total population. It is characterized by abundant palm groves and arable farmlands. The great Mosque of Qalat Saleh is one of its significant heritage landmarks, established in 1868, during the era of the Ottoman Empire, when the castle was built. Qalat Saleh primary school is located in front of the mosque and it is one of the heritage buildings. The school was founded 
in 1926 by a British commander. The shrine of Imam Abdullah bin Ali is $11 \mathrm{~km}$ away from the district. The city is located on the highway from Amara to Basra, and the Tigris River passes nearby.

\subsection{Urbanization pattern}

Table 1. Expectations of an increase in the urban population in the Qala'at Salih District (Source: Ministry of Planning in Iraq - Maysan structural plan study).

\begin{tabular}{|c|c|c|c|c|c|}
\hline District & 2012 & 2018 & 2023 & 2028 & 2033 \\
\hline Qalaat salih District center & 37,901 & 44,951 & 50,738 & 56,650 & 62,090 \\
\hline Uzair & 11,728 & 13,909 & 15,700 & 15,700 & 15,700 \\
\hline & \multicolumn{5}{|c|}{ Expectations of an increase in the rural population in Qalaat Salih } \\
\hline Qalaat salih District center & 14,529 & 16,386 & 18,274 & 19,787 & 21,420 \\
\hline Uzair & 10,440 & 11,775 & 13,131 & 14,218 & 15,392 \\
\hline
\end{tabular}

One of the major challenger associated with urbanization is creating opportunities for investments and jobs, and facilitating local economic development. These activities require cities to have attractive enabling environments for investment and opportunities for development and rehabilitation of degraded areas in both urban and rural context. Most of the population is concentrated in the urban centers of the Missan governorate, mostly in the city of Amarah, where the urban population accounts for $89 \%$, while the rural population does not exceed $11 \%$, contrary to the case in Maymouna and Kahla. Qalat Saleh reported almost equal percentages for both urban and rural populations (Fig. 2).

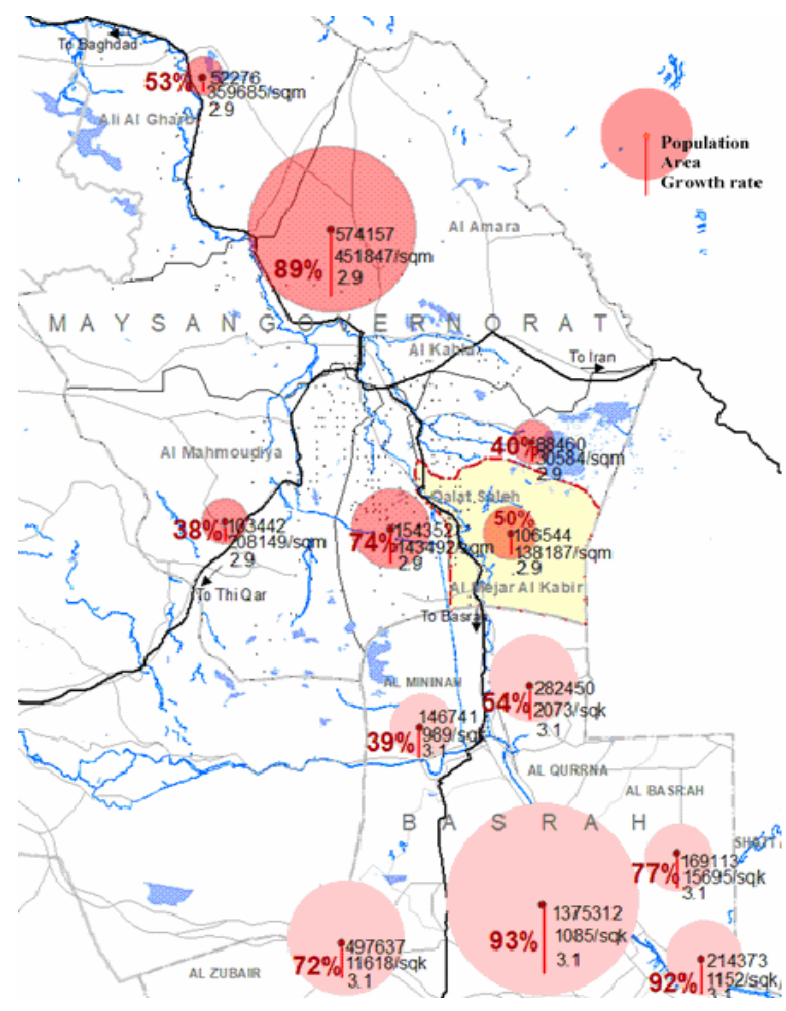

Fig. 2. Location and urbanization pattern of QS on Amara-Basra highway (Source: Open Street Map-GIS and data of Ministry of Planning in Iraq).

60
The population is projected to concentrate in urban areas as a result of the urbanization trends (United Nations, 2012), as indicated in the study of Missan structural plan (Heilig, 2012) which outlines the district's projections (Table 1).

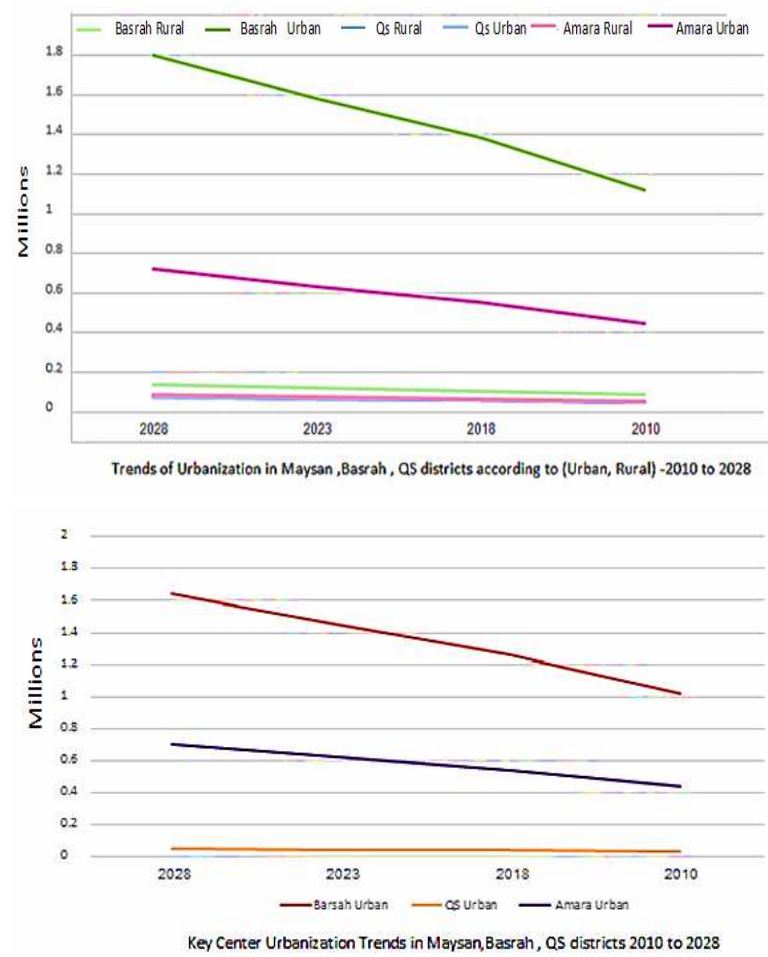

Fig. 3. A, B. Comparison of urbanization trends between urban and rural areas in Amarah, Basra, and Qalat Saleh districts from 2010 to 2028 (Source of data: Central Statistical Origination (CSO), Ministry of Planning in Iraq).

Qalat Saleh is surrounded by a number of rural villages. The surrounding rural areas depend mainly on the urban settlement to provide for their needs, and there is also a migration of the neighboring rural population towards the town. The city has a relatively high population growth rate; the unemployment rate is reported at about $8.4 \%$ of the total number of workers in Qalat Saleh. The average household size is large even compared to the national average, with occurrence of overcrowding in dwellings (more than one family in a single dwelling in addition to the large household size), as well as informal settlements due to inadequate housing and lack of access to affordable residential land plots by the poor. Many areas can be used for housing 
or selected as expansion areas in accordance with the availability of resources and transport routes, which will make cities positively interconnected and benefit from the economies of agglomeration along the development corridor.

\subsection{Regional Development potential for Qalat Saleh (QS)}

\subsubsection{Tourism potential}

Four landscape areas can be distinguished in Missan (Fig. 4) as follows:

a). The river: along the course of the Tigris River, the riverfront in Qalat Saleh can be exploited for tourism purposes.

b). The agricultural zone and the marshes to the left of the governorate.

c). The desert zone northeast of the city.

d). A development hub for industrial, agricultural, and oil activities (there is a need to develop strict constraints for the non-interference with natural ecosystems) within the city.
Marshlands landscape: The riverfront in Qalat Saleh can be exploited for tourism purposes. The tourism potential of the ecological characteristics in Qalat Saleh region is noticeable. Investment in recreational and tourism facilities is insufficient; however, its position on the river and its proximity to the Marshes provide great opportunities for tourism development. The location of Qalat Saleh on the road leading to Amarah and Basra, and the presence of 5 religious shrines as shown in Figure 3 makes Qalat Saleh a transit area during pilgrimage events (the shrine of Abdullah bin Ali, which is $10 \mathrm{~km}$ from the city, the shrine of Prophet Uzair to the south, about $27 \mathrm{~km}$ from the urban center of Qalat Saleh, the shrine of Ali al-Zaki on the road to Kahla, and the shrines of Ali al-Gharbi and Ali al-Sharqi which are located in the district of Ali al-Gharbi). This location can be invested in the creation of a tourism and religious development corridor along the transport route, thereby providing services and land uses in line with the activities of this region such as guesthouses, travel agencies, bus/taxi points restaurants and shops, as well as the restoration and development of archaeological and heritage sites that would give the city a special significance.

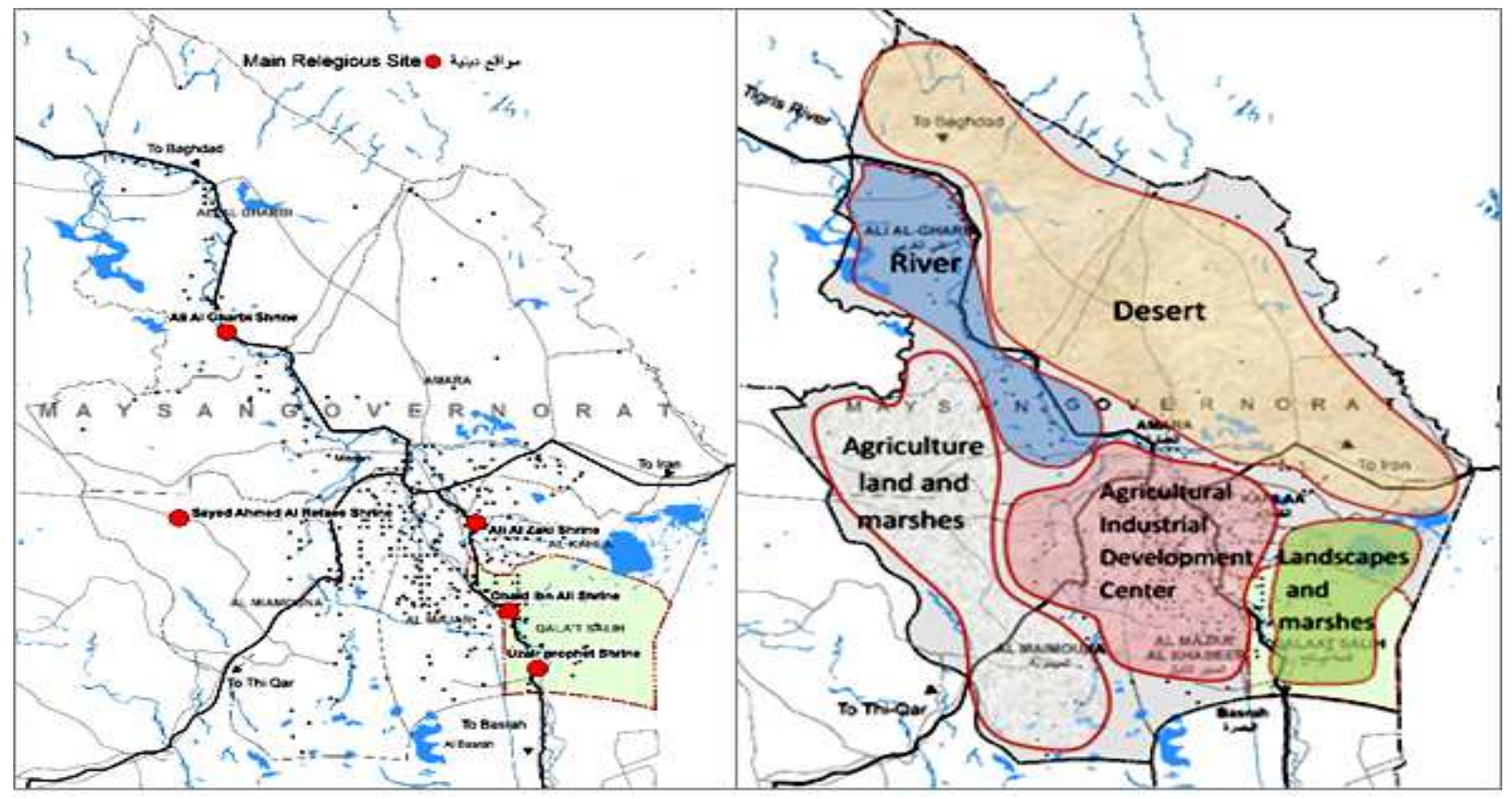

Fig. 4. A- Religious sites and shrines visited by Shiaa and pilgrimage in Maysan governorate. Source: Arc map B. Ecological characteristics in Maysan the figure shows that QS with the marshes area (Source: Ministry of Planning in Iraq).

\subsubsection{Agricultural potential}

The area of arable land in the district of Qalat Saleh was reported at 40,066 hectares while nonarable land area was about 34,006 hectares (Heilig, 2012) (Al-Abadi and Al-Shamma'a, 2014). It is one of the cities with less arable land compared to the other districts of the governorate. This does not necessarily mean that there is no good potential at the district level, as there is a considerable amount of arable land in the district itself. There is also a good potential for the production of animal feedstuff; this necessitates increasing fodder crops production and selling of the surplus to adjacent sub-districts where there are imbalances between fodder production and consumption, as well as a need to increase their fodder crops production or have it purchased from neighboring markets such as Al Maymouna district. 
There is a future for planting vegetables since the availability of water is guaranteed. There is sufficient space for meat and milk processing plants. Focus on green fodder crops is possible, as well as opportunities to support the poultry sector. This will require advanced irrigation techniques for the purpose of expanding agriculture and increasing meat and milk production. It is also noteworthy to mention the important role of the Marshes that can be invested in tourism, fishing, breeding livestock and birds of all kinds, in addition to the boating industry. The district is characterized by the industries of construction materials such as bricks, and the availability of specialized labor. Crops exported from Qalat Saleh to neighboring governorates and districts include dates and some summer crops; hence the establishment of factories for the packing of dates can be encouraged.

\subsubsection{Industry and employment in Qalat Saleh}

The poverty rate in the district of Qalat Saleh is reported at 71.6, which is almost the highest rate after al-Kahla district according to the Ministry of Planning (Fig. 6).

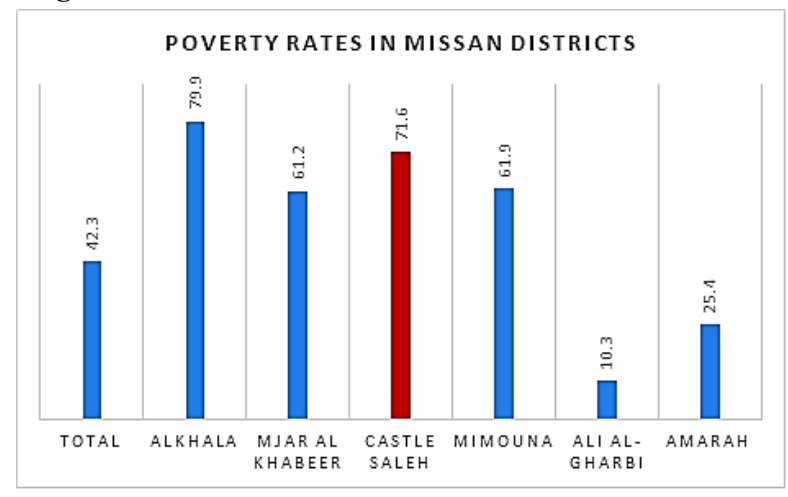

Fig. 6. Poverty rates in Mayssan districts. (Source: Ministry of Planning - Department of Local and Regional Development)

This means that focusing on activities that can reduce poverty and provide job opportunities for citizens is required. Therefore, the city should expand and diversify its domestic industrial and economic base because the income prospects and the sustainable employment opportunities creation may be achieved through the self-sufficiency of the city. It is, therefore, best to find ways to focus on local socio-economic development to promote further internal growth and economic development so that it would be possible to mobilize capital, resources, and local expertise to develop local export and investment opportunities.

An industrial corridor may be created given the advantage of low-cost labor and the availability of resources. As a result of the economies of agglomeration, a multitude of industries will be attracted with lower wages of labor or greater access to markets or both along the development corridor.
This will create new job opportunities for residents and should be highlighted. As for the private sector industries, there is one large industrial facility in Qalat Saleh that employs about 50 workers, which is the lowest number of workers compared to the number of empolyees in the large private sector industrial facilities in the rest of the districts. There are 57 small industrial facilities in the district and is ranked third after the districts of Amarah and Al Mijar Al Kabeer. The number of workers is reported at 77 and comes in fourth place after the districts of Amarah, Al Mijar Al- Kabeer, Ali $\mathrm{Al}-\mathrm{Gharbi}$ and Khala as shown in figure 7.

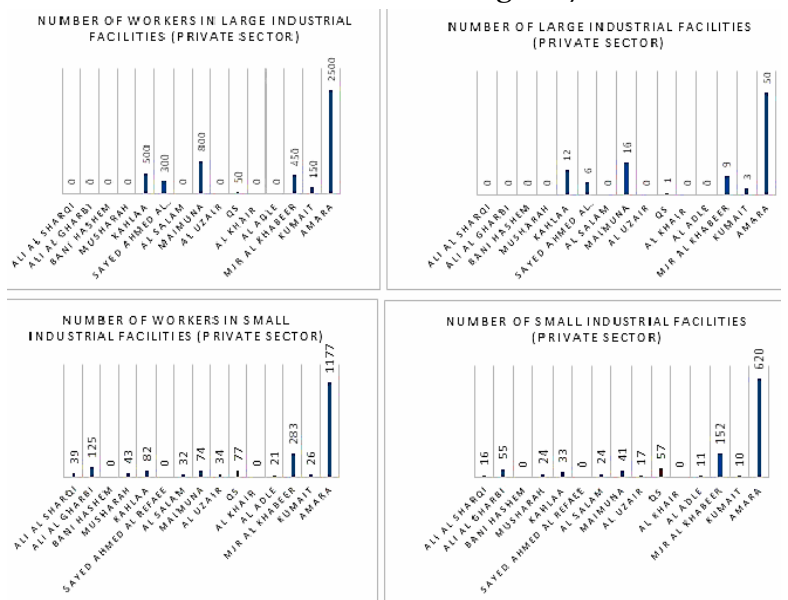

Fig. 7. Number of industrial facilities and workers in Maysan districts (Source: Ministry of Planning - Department of Local and Regional Development).

\subsubsection{Industrial complex distribution}

The following map shows the density and distribution of production sites in various locations of the governorate. Among the companies surveyed in the study of the Maysan structural plan, there are 33 brick factories in Amara district and 18 in Al-Maymunah. The main industry in terms of labor volume is the general sugar industry company located in the district of $\mathrm{Al} \mathrm{Mjr}$ Al-Kabeer on the Amara-Mjr highway. The factory is currently not functional/not in use due to the lack of equipment. Qalaat Salih has a 2-industrial complex of gas. According to the field survey of Soka Gakkai International (SGI) 2012, it is clear that more than $45 \%$ of the registered companies are located in the district of Amarah. The production capacity of the companies producing bricks is more than one million pieces per year and accounts for more than $50 \%$ of the total labor force in the governorate. The main industrial facilities indicated above are found mainly in the districts of Amarah (oil plant, plastics factory), Mjr AL Kabeer (paper factory and sugar factory) and Al-Musharrah (refinery).

The largest number of production sites consists of brick factories built in different clusters located on the roads between Amara and Mjr, between Amara and Maimouna, between Al Maimouna and Sayed Ahmed Al Refai, as well as between Al Amara and 
Kmait. There are 26 brick industries in Amara and 15 in Maimouna. In Mimouna, the maximum capacity of the brick production is more than ten million pieces per year.

Along the development corridor, a number of industrial facilities are found along the road from Amara to Qalat Saleh, including brick factories, a paper factory, a sugar cane plantation, a sugar mill, and an oil factory. The rest of the land is agricultural land used by farmers (contracted or owned). Some of these factories are currently not functioning and need to be reoperated, as well as the establishment of some necessary industries along the development corridor to cater for all the urban centers along the development corridor, including Qalat Saleh - Al Mijar Al- Kabeer Kahla - all the way to Amarah.

There are employees from Qalat Saleh they working in the neighboring governorates and districts, but their numbers could not be identified due to the lack of statistical data and the absence of a modern survey of the area. However, people of the area are aware that some of the city's residents are working in the Oil companies in Missan, sugar mill and paper factory at Al Mijar Al- Kabeer, projects that create jobs in Qalat Saleh, Dates processing plants, Dairy factories, Water bottling, and purification plant, Governmental or private sector construction plants (Fig. 8).

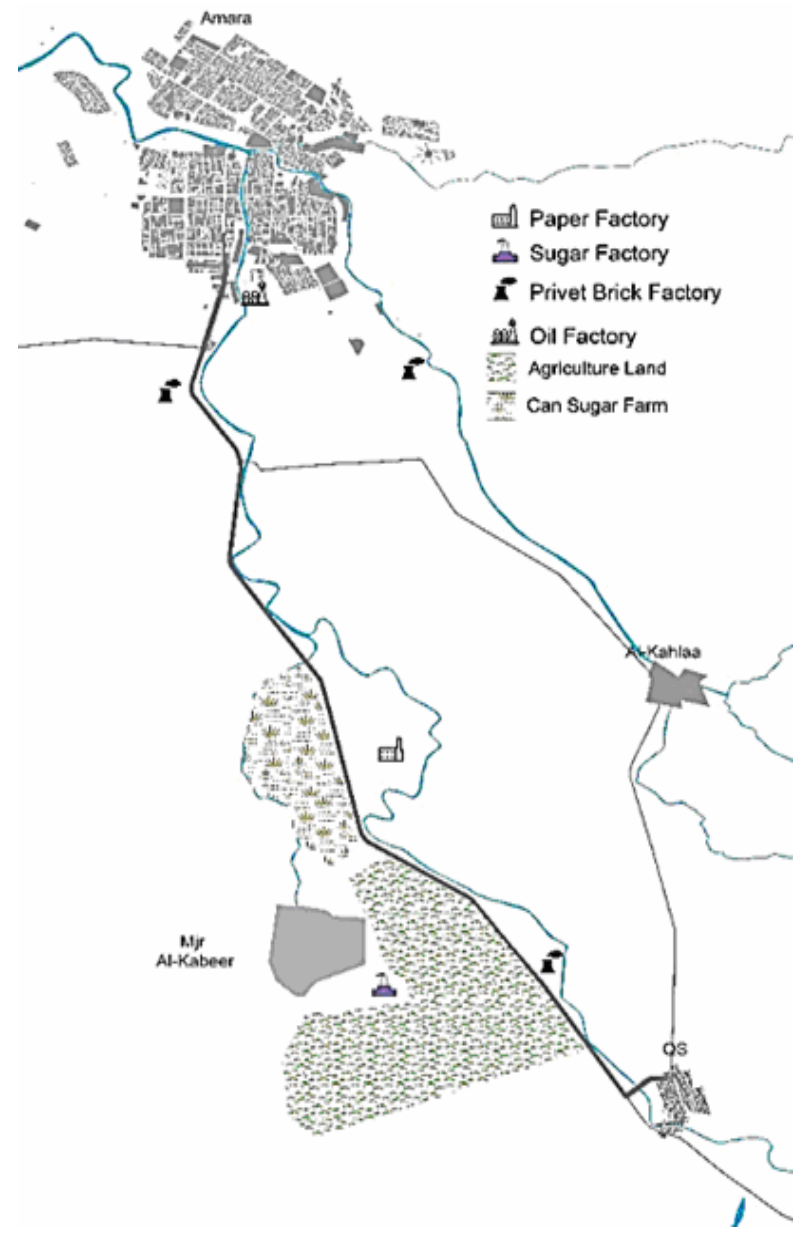
corridor.

\subsubsection{Transport potentials}

The role played by the transport sector at the economic, social and urban levels cannot be ignored. The impact of the development achieved in this sector extends across all other sectors. Its contribution is reflected in the growth of cities and urban settlements located along the development corridor and in accommodating the increasing numbers of the incoming population both in new expansion areas or within the urban areas located along the road. The location of Qalat Saleh on the highway, connecting it with Amara to the north and with the cities located to the south, provides the potential of linking urban settlements and provides access to roads that will attract activities and achieve economic, social and cultural integration.

Improved road networks between districts provide opportunities for the development of new cities along the transport route, as secondary cities located on simple transport routes may evolve into full economic corridors. Not all corridors are intended to become economic corridors, but intermediate corridors (trade, freight, industrial, agricultural, etc.). Roads are classified into two types according to Maysan directorate data; these are intra-district and interdistrict roads. With respect to the roads outside the district, the main road between Amarah and Basra is in good condition since its paved part accounted for $100 \%$ of the total length of the road. It is suitable for transport with good quality as it is a dual carriageway road with a total length of about $70 \mathrm{~km}$. Qalat Saleh-Kahla road is a secondary road with a total length of about $17 \mathrm{~km}$. The paved part is about $15 \%$. It is a single carriageway road and its suitability for transport is medium. The other secondary road is Qalat Saleh-Abu Ajal, a $25 \mathrm{~km}$ fully paved single carriageway road in a medium condition. As for the lengths of the internal roads and sidewalks, the 2010 data indicate that the total length of the roads is of about $48,750 \mathrm{~km}$, of which about $39,750 \mathrm{~km}$ was paved while subbase covered roads were about 9,000 linear meters. Sidewalks were around $17,000 \mathrm{~km}$ in length. Compared to the rest of the governorate districts, Qalat Saleh reported the highest rate of paved roads in the governorate of Missan at about $82 \%$, next to Amarah. The proportion of subbase paved roads amounted to $18 \%$, while roads with sidewalks were about $35 \%$, the highest value at the governorate level . The governerate still needs the development of rural roads, which should link villages and rural areas to the district center and the maintenance and rehabilitation of existing rural roads.

\subsubsection{Trade potential}

The growing levels of trade and transport along the economic trade corridor will lead to the 
emergence of other secondary cities. The impact of major cities on trade, transport, and communications will also have significant implications on the way secondary cities function. Building networks, links and market systems that feed large urban settlements, such as Amarah, is critical to the development of trade, which will attract investments in the business sector in Qalat Saleh. Secondary cities that do not upgrade their infrastructure and are unable to connect to markets and commercial systems dominated by major and large urban settlements would not only lose export opportunities, but this fact will also affect opportunities for the development of domestic trade within local economies.

All cities are interlinked and interdependent on each other to work and grow in modern economies, and trade will become increasingly important for the development of secondary city systems. This is important for creating jobs and investment opportunities to provide a more sustainable domestic basis for the economic growth. The increasing levels of trade and travel between cities lead to the emergence of a new type of secondary cities that develop along the trade / economic growth corridor.

Regarding the urban area, the $\mathrm{CBD}$ and the grand Bazar area are old and worn out, extending in a linear shape, and suffering from traffic congestion and low level of investments. Local markets are small and generally insufficient. There is only one wholesale market for fruit and vegetables in the city, which is not enough for the marketing of agricultural products of the neighboring villages as it has a few structures that include only the fence and some simple shops. At the largest level among districts, there are no commercial exchange sites on the development corridor, but there are some trade exchanges between the districts, such as exporting dates in the summer to Al-Basra, and the import of fruit from the outside district, for example, fruit import from $\mathrm{AL}-\mathrm{Mjr} \mathrm{Al}$ Khabeer.

\section{DISCUSSION}

The scientific relevance of this study is its importance in directing cities towards creating a regional balance in the planning process; this will serve as a reference to decision-makers, workers in planning institutions, and state officials to the importance of directing cities to the idea of sustainable urbanization, thereby relieving over-dependence on large cities and portraying the importance of focusing development efforts on secondary cities located within the development corridors. With the same capabilities and resources, it encourages investments in a way that makes them a development pole to relieve pressure on those cities. Qalaat Salih is a good case study for this research as it is located on a development corridor between cities characterized by large population size
(Basra and Amara); so there is a huge migration of people to the city and this may be a threat to the rest of the population settled in the areas between those cities and villages. The research connected the findings of the articles of Müller-Mahn (2019) - How futures are 'made' and how practices of future-making can be empirically approached, and Méreiné Berki et al. (2017) - The importance of the possible poverty alleviation interventions relating to social capital. These findings were transformed into a development proposal in this study.

The study of Athukorala and Narayanan (2018) highlighted the problems faced by the process of infrastructural development within an equitable corridor development program; so, this research recommends more studies on the provision of infrastructure for secondary cities along a development corridor. Regarding the study of Wan et al. (2017) on the industrial corridor, there is a certain influence of population growth but the major factor responsible for the deterioration of the ecological environment is predatory resources development and irrational development practices. Thus, this study recommends the need to think about the environment, as well as achieving the lowest level of environmental pollution and resource consumption, the least level of energy consumption, and the least quantity of emissions. There is also a need for more studies in the future regarding our case study in Qalaat Salih.

\section{CONCLUSIONS AND RECOMMENDATIONS}

Strengthening the particular developmental role to be played by Qalaa Saleh (such as agriculture or tourism), linking it to major cities based on a planning hierarchy, and providing interconnectivity via modern and advanced land transport networks will enable interaction with each other in accordance with effective and vibrant economic, social and urban dynamics. It is possible to exploit the natural resources, the existence of the Marshes, as well as enhance tourism development using resources available along the selected development axis, Amara - Qal'at Salih. Possible import and export opportunities between the districts can also be explored. For example, there is a possibility of producing fodder in the district of Qalaa Saleh, thereby providing the districts that lack it with the opportunity to buy, and the same in the case of the rest of potentials. Villages and rural areas can be rehabilitated and provided with services and support to leverage their resources in order to sustain their own development.

Activities that attract labor and exploitation of potentials and opportunities for development can be located in the area. For example, in Qal'at Salih, some small, non-polluting industries, such as dairy factories, filling and purification plants can be established. 
There is a need for an updated and comprehensive database of all sectors and resources in the cities and areas connecting villages and cities and between the centers of districts and neighboring districts and governorates. Without this database, it may be difficult to work on a comprehensive analytical framework; therefore, the creation of a unified data platform for all governmental institutions that will be centrally managed and updated is recommended.

The concept of concentrated expansion should be adopted within the framework of an integrated development corridor in line with the spatial strategy by giving priority to development areas with diversified economic pillars (agriculture, industry, tourism) to achieve the integration of the development system:

a). The development of rural and small settlements along the development corridor should be promoted.

b). The rural settlements and agricultural areas should be developed by placing population concentrations beside them.

c). The development of a connected urban fabric through the spread of multi-functional development areas and nodes should be encouraged as it will contribute to reducing the cost of facilities and will support the means of communication.

d). The existing development nodes should be developed and interconnected by creating activities that contribute to the development of industrial, commercial and tourist activities.

e). The focus should be on upgrading urban nodes to become magnets that function as satellite towns.

New urban agenda should be adopted at the regional and local level as an action assessment tool for sustainable urban and human development through the formulation of a sustainable urban management program.

The qualitative disparity between services provided to urban and rural areas should be minimized. Priority should be given to developing programs targeted at the poor and vulnerable groups living in informal settlement areas.

There should be diversity and social inclusion/integration at the regional and local levels. Urban and rural areas should have a form of integration to support each other.

Sustainable access to basic services in all settlements, as well as infrastructure development between new and existing development nodes, should be ensured.

Business development areas should be established for specific industries on the basis of proximity to resource extraction sites; manufacturing units should also be established near the available local manpower. Industrial activities should also be fostered along the development corridor to reduce unemployment and provide attractive job opportunities for the district population.

\section{ACKNOWLEDGEMENTS}

This research is supported by UN-HABITAT 2018 as one of the projects of the Local Area Development Program (LADP).

\section{REFERENCES}

Abdulkhaleq S., Abdulqadir Z. (2017), The Effect of Foreign Direct Investment on Economic Growth: Evidence from Iraq. International Journal of Social Sciences \& Educational Studies, 3(4), 89-97. DOI: https://doi.org/10.23918/ijsses.v3i3p89

Al-Abadi A., Al-Shamma'a A. (2014), Groundwater potential mapping of the major aquifer in Northeastern Missan Governorate, South of Iraq by using analytical hierarchy process and GIS. Journal of Environment and Earth Science, 4(10), 125-149. URL: https://www.iiste. org/Journals/index.php/JEES/article/view/13229

Allen C., Metternicht G., Wiedmann, T. (2016), National pathways to the Sustainable Development Goals (SDGs): A comparative review of scenario modelling tools. Environmental Science \& Policy, 66, 199-207. DOI: https://doi.org/10.1016/j.envsci.2016. 09.008

Athukorala P.-C., Narayanan S. (2018), Economic corridors and regional development: The Malaysian experience. World Development, 106, 1-14. DOI: https://doi.org/10.1016/j.worlddev.2018.01.009

Catalán B., Saurí D., Serra P. (2008), Urban sprawl in the Mediterranean?: Patterns of growth and change in the Barcelona Metropolitan Region 1993-2000. Landscape and Urban Planning, 85, 174-184. DOI: https://doi.org/10.1016/j.landurbplan.2007.11.004

Cities Alliance (2007), Liveable Cities - The Benefits of Urban Environmental Planning, A Cities Alliance Study on Good Practices and Useful Tools. Cities Alliance. ICLEI/UNEP, Washington. URL: https:// www.asclibrary.nl/docs/408643102.pdf. Accessed on 12.05.2018.

Creţan R., Jucu S., Antoni M. (2016), Anisotropic spaces in Romania: a case study of the Timiş-Cerna Corridor. Acta Geographica Slovenica, 56, 45-56. DOI: https://doi.org/10.3986/AGS.840

Central Statistical Origination (CSO) (n.d.) Ministry of Planning in Iraq. URL: http://www.cosit. gov.iq/en/. Accessed on 11.09.2018.

United Nations (2012), World Urbanization Prospects: The 2011 Revision. United Nations, Department of Economic and Social Affairs. Population Division, New York. URL: https://www.un.org/en/ development/desa/population/publications/pdf/urbani zation/WUP2011_Report.pdf. Accessed on 15.06.2017.

Fahad A. Y., Ahmed M. (2016), The Impact of Corruption on Foreign Direct Investment (FDI) in Post- 
Conflict Countries: A Panel Causality Test. Journal of Advanced Social Research, 6(3), 1-12. URL: https://portal.arid.my/Publications/oee3b2ba-63of493b-a735-6do3edaeod18.pdf

Faihan S. (2014), Urban Policy In Iraq for the Period 1970-2012, Evaluation Study. Journal of Advanced Social Research, 4(3), 58-76.

UN-Habitat (2013), State of the world's cities 2012/2013: Prosperity of cities, Routledge. ISBN-10: 9780415838887. URL: https://sustainabledevelopment .un.org/content/documents/745habitat.pdf

Heilig G. K. (2012), World urbanization prospects: the 2011 revision. United Nations, Department of Economic and Social Affairs (DESA), Population Division, Population Estimates and Projections Section, New York, 14. URL: https://population.un.org/wup/Publica tions/Files/WUP2014-Methodology.pdf. Accessed on 18.07.2018.

John P., Mossberger K., Clarke S. E. (2015), The Oxford handbook of urban politics, Oxford University Press. ISBN-13: 978-0199385553. DOI: 10.1093/ oxfordhb/9780195367867.001.0001

Martinuzzi S., Gould W. A., Ramos González O. M. (2007), Land development, land use, and urban sprawl in Puerto Rico integrating remote sensing and population census data. Landscape and Urban Planning, 79(3-4), 288-297. DOI: https://doi.org/ 10.1016/j.landurbplan.2006.02.014

Méreiné Berki B., Málovics G., Toth J., Creţan R. (2017), The Role of Social Capital and Interpersonal Relations in the Alleviation of Extreme Poverty and Spatial Segregation of Romani People in Szeged. Journal of Urban \& Regional Analysis, 9 (1), 33-50. URL: $\quad$ http://www.jurareview.ro/resources/pdf/ volume_19_the_role_of_social_capital_and_interpers onal_relations_in_the_alleviation_of_extreme_povert y_and_spatial_segregation_of_romani_people_in_sze ged_abstract.pdf

Müller-Mahn D. (2020), Envisioning African Futures: Development corridors as dreamscapes of modernity. Geoforum, 115, 156-159. DOI: https://doi.org/10.1016/j.geoforum.2019.05.027.

Ministry of Planning in Iraq (n. d.) Maysan structural plan study. URL: https://planipolis.iiep. unesco.org/sites/planipolis/files/ressources/iraq_natio nal_development_plan_2018-2022_arabic.pdf.

Accessed on 17.10.2018.
Pantuliano S., Metcalfe V., Haysom S., Davey E. (2012), Urban vulnerability and displacement: a review of current issues. Disasters, 36(S1), S1-S22. DOI: https://doi.org/10.1111/j.1467-7717.2012.01282.x

Roberts B. H. (2014), Managing systems of secondary cities: Policy responses in international development. Brussels: Cities Alliance: Cities without Slums. ISBN: 978-9-0822617-1-4. URL: https://www.citiesalliance. org/sites/default/files/1d\%2O(i)\%2O-

\%20Managing\%20Systems\%20of\%20Secondary\%20Cit ies\%20Book_low_res.pdf

Rogerson C. (2016), Secondary cities and tourism: The South African record. African Journal of Hospitality, Tourism and Leisure, 5(2). URL: http://www.ajhtl.com/uploads/7/1/6/3/7163688/2016 _article_23_vol_5__2_.pdf

Salat S., Bourdic L., Kamiya M. (2017), Economic foundations for sustainable urbanization: a study on three-pronged approach: planned city extensions, legal framework, and municipal finance. Urban Morphology and Complex Systems Institute, Paris/Urban Economy Branch, UN-HABITAT, Nairobi. URL: https:// unhabitat.org/economic-foundations-for-sustainableurbanization-a-study-on-three-pronged-approachplanned-city-extensions-legal-framework-andmunicipal-finance. Accessed on 17.11.2018.

Vesalon L., Crețan R. (2019), "Little Vienna" or "European Avant-Garde City"? Branding Narratives in a Romanian City. Journal of Urban and Regional Analysis, 11(1), 19-34. URL: http://www.jurareview.ro/ resources/pdf/volume_27_\%E2\%80\%9Clittle_vienna \%E2\%80\%9D_or_\%E2\%80\%9Ceuropean_avantgarde_city\%E2\%80\%9D_branding_narratives_in_a_r omanian_city_abstract.pdf

Wan L., Zhang Y., Qi S., Li H., Chen X., Zang S. (2017), A study of regional sustainable development based on GIS/RS and SD model-Case of Hadaqi industrial corridor. Journal of Cleaner Production, 142, 654-662. DOI: https://doi.org/10.1016/j.jclepro.2016. 09.086

Wang Y. (2020), Urban land and sustainable resource use: Unpacking the countervailing effects of urbanization on water use in China, 1990-2014. Land Use Policy, 90, 104307. DOI: https://doi.org/ 10.1016/j.landusepol.2019.104307 